\title{
INFLUENCE OF SULFURIC ACID ATTACK ON CONCRETE WITH INDUSTRIAL WASTE
}

\author{
Adriana Estokova \\ Institute of Environmental Engineering, Faculty of Civil Engineering, Technical University of Kosice, \\ Slovakia, Prof. Dr. \\ Corresponding author: adriana.estokova@tuke.sk \\ Michaela Smolakova \\ Institute of Environmental Engineering, Faculty of Civil Engineering, Technical University of Kosice, \\ Slovakia, Eng.
}

\begin{abstract}
The paper aims at investigating cement composites with incorporated wastes such as blast granulated slag, fly ash, or micro silica regarding their durability and resistivity against aggressive acidic environments. An aggressive acidic attack was simulated with $\mathrm{H}_{2} \mathrm{SO}_{4}$ with a pH of 1.95. The experiments proceeded under model laboratory conditions over a period of 6 weeks, and the accelerated tank leaching test was applied. Both physical (mass of samples, water absorption, and surface disruption) and chemical parameters of concretes ( $\mathrm{pH}$, leachability of main components, chemical composition) were examined. The changes in the mass of samples, surface changes, as well as absorbability increases were observed after exposure to sulfuric attack. The leached-out amounts of calcium, silicon, aluminum, and iron, measured using X-ray fluorescence analysis, varied depending on the composition of the analyzed composite and the kind of waste incorporated. The samples with micro silica and slag were identified to be the most durable, regarding the leaching of basic inorganic compounds of the cement matrix. The sample with fly ash was observed to have the lowest change in water absorbability. The positive effect of incorporating waste into cement composite was confirmed when compared to a concrete sample without any waste added.
\end{abstract}

Keywords: cement composite; slag; fly ash; micro silica; durability

\section{UTJECAJ SULFATNE KOROZIJE NA BETON S INDUSTRIJSKIM OTPADOM}

Sažetak: Cilj rada je ispitati trajnost cementnih kompozita u čjem sastavu se nalaze granulirana troska, leteći pepeo ili silikatna prašina, kao i njhovu otpornost na agresivan kiseli okoliš. Kiselinska korozija je simulirana $s$ H2SO4 s pH vrijednošću od 1,95. Mjerenja su provedena u laboratorijskim uvjetima tjekom perioda od 6 tjedana, uz primijenjeni ubrzani test izluživanja. Ispitana su fizikalna (masa uzoraka, upijanje vode, površinska oštećenja) i kemijska (pH vrijednost, izluživanje glavnij sastojaka, kemijski sastav) svojstva betona. Zapažene su promjene u masi uzoraka, izgledu površine te upijanju vode nakon izloženosti kiselinskoj koroziji. Količine izluženog kalcija, silicija, aluminija i željeza, izmjerene pomoću rendgenske fluorescentne analize, varirale su ovisno o sastavu analiziranog kompozita i vrsti upotrijebljenog otpadnog materijala. Uzorci sa silicijskom prašinom i troskom pokazali su najveću trajnost s obzirom na izluživanje osnovnih anorganskih spojeva cementne matrice. Uzorak s letećim pepelom pokazao je najmanju promjenu u upijanju vode. Uporabom otpadnih materijala u betonu ostvario se pozitivan učinak na trajnost betona.

Ključne riječi: cementni kompozit; troska; leteći pepeo; silicijska prašina; trajnost 


\section{INTRODUCTION}

Vast amounts of cement-based materials such as concrete are used in wastewater facilijes such as sewers, reservoirs, and treatment plants [1]. Sewer systems are essential infrastructures that play a key role in the economy, social well-being, and quality of life of a country.

The anaerobic conditions in the buried sewers often lead to complex biochemical and chemical transformations. The results of chemical reactions and transformations are sulfate attack, corrosion, and deterioration of the pipe material [2]. The consequences of the deteriorated sewers can be economically, environmentally, and socially devastating because of the massive costs associated, disruption of daily life, and pollution [2].

It is also believed that the climate change-induced temperature rise will further accelerate corrosion of wastewater concrete structures. At the end, the corrosion will lead to reduction of wall thickness, resulting in structural collapse of the sewer or the whole system. Because of these negative impacts of corrosion, protective measures have to be carried out [2].

It has been recognized that industrial by-products such as micro silica, fly ash, and blast furnace slag act as pozzolans or supplementary cementitious materials and they possess good resistance to chemical corrosion. This property makes them suitable for use in a variety of essential structures [3]. Extensive amounts of waste byproducts are generated around the world [4]. The disposal of these wastes cause significant environmental problems. Therefore, recycling and reuse of these waste materials as fillers in the cement and concrete industry are of great importance to environment protection [5].

Investigating the durability properties of mortar and concrete by using supplementary cementitious materials is one of vital issues and a current demand in the research on concrete [6]. Pozzolans are artificial or natural fine materials that can partially replace cement in concretes. The main component of pozzolans is amorphous silica. Amorphous silica reacts in the presence of water with calcium hydroxide $\left(\mathrm{Ca}(\mathrm{OH})_{2}\right)$, creating compounds with cementitious properties. Pozzolanic materials can also have amorphous alumina in their composition, producing alumina-silicates as well as in cements. Two main factors, namely, the maximum amount of calcium hydroxide that can react with a pozzolan and the speed at which the pozzolanic reaction occurs define the reactivity of the pozzolan [7]. Besides pozzolanic reactivity, these materials also have a filler effect, which is described as a decrease in the total porosity of the system due to the filling of voids and capillary pores [8, 9]. The filler effect can justify the improvement in mechanical strength, decreased water absorption by capillarity, improved resistance to chemical attacks, and increased durability of concrete [9].

Sulfate attack is a vital issue regarding the performance of concrete resulting in strength reduction and degradation $[10,6]$. It is well-documented that cement-based materials incorporated with pozzolans have improved resistance to acid attack and sulfate attack compared to materials made only with ordinary Portland cement $[11,6]$. Thomas et al. [12] and Thomas [13] reported that the use of pozzolanic materials is extremely advantageous not only to minimize the environmental pollution but also to enhance the durability of concrete [14].

The objective of the present study is to investigate the durability of concrete composites with various incorporated waste materials (fly ash, micro silica, and granulated blast furnace slag) against sulfuric acid attack, evaluating the changes in chemical and mechanical parameters of the analyzed samples.

\section{MATERIALS AND METHODS}

Four mixtures were designed for the experiment. $\mathrm{A} 0$ represents the mixture with cement only, made with ordinary CEM I Portand cement. To compare the resistance of the composites with different waste materials, it is appropriate to have samples made only with ordinary Portland cement to determine the differences between the traditionally used cement mixture and the modified mixtures with waste products.

In the other three mixtures, cement was partially replaced by supplementary cementitious materials as micro silica (A1), fly ash (A2), and furnace slag (A3), respectively. The compositions of these mixtures were prepared in accordance with STN EN 206-1+A1 [15]. Specific mixture proportions with appropriate water-to-cement ratio (w/c) for specimens are given in Table 1. The composition of the mixtures was designated in cooperation with the praxis to incorporate real waste materials and also based on the previous knowledge regarding the recommended quantities of specific secondary materials in terms of the chemical resistance in acidic environments. The samples Estokova, A, Smolakova, M 
are supposed to be more resistible and durable when more blast furnace slag is included, according to Özbay et al. [16] and Osborne [17].

Table 1 Composition of concrete specimens (per cubic meter of fresh concrete)

\begin{tabular}{ccccc}
\hline Composition & A0 & A1 & A2 & A3 \\
\hline Cement $\left[\mathrm{kg} / \mathrm{m}^{3}\right]$ & 358.55 & 360 & 304.75 & 90 \\
Natural aggregates, fraction $0 / 4 \mathrm{~mm}\left[\mathrm{~kg} / \mathrm{m}^{3}\right]$ & 845 & 750 & 845 & 825 \\
Natural aggregates, fraction $4 / 8\left[\mathrm{~kg} / \mathrm{m}^{3}\right]$ & 405 & 235 & 405 & 235 \\
Natural aggregates, fraction $8 / 16\left[\mathrm{~kg} / \mathrm{m}^{3}\right]$ & 590 & 740 & 590 & 740 \\
Water [L/m $\left./ \mathrm{m}^{3}\right]$ & 190 & 191 & 190 & 162 \\
Micro silica $\left[\mathrm{kg} / \mathrm{m}^{3}\right]$ & - & 20 & - & - \\
Fly ash $\left[\mathrm{kg} / \mathrm{m}^{3}\right]$ & - & - & 41.3 & - \\
Blast furnace slag $\left[\mathrm{kg} / \mathrm{m}^{3}\right]$ & - & - & - & 270 \\
Plasticizer $\left[\mathrm{L} / \mathrm{m}^{3}\right]$ & - & 3.1 & - & - \\
Water-to-binder ratio $(\mathrm{w} / \mathrm{b})$ & 0.53 & 0.50 & 0.55 & 0.44 \\
\hline
\end{tabular}

The prepared standardized concrete prisms of size $100 \times 100 \times 400 \mathrm{~mm}$ were cured for 28 days in water and afterwards cut into small prisms with dimensions of $50 \times 50 \times 10 \mathrm{~mm}$. Before the experiment, the samples were brushed to remove polluting particles, cleaned, dried, and weighted.

Dry test specimens were exposed to sulfuric acid with a $\mathrm{pH}=1.95$ and the $\mathrm{pH}$ value of acid was kept on a constant level during the experiment. The volume of the liquid media was derived from the volume of the concrete prisms and was set to the ratio 10:1. The exposition of concrete samples took place in glass containers over a period of 6 weeks at laboratory temperature of $23^{\circ} \mathrm{C}$. After placing samples into sulfuric acid solution, a chemical composition of concrete samples' leachates were investigated every 14 days. Water absorbability was measured before and after 6 weeks of the experiment on the same specimens.

The absorptivity test was performed on all concrete specimens in accordance with the standard STN 731316 [18] by measuring the masses of dry and wet samples before and after the experiment. Water absorbability $(v)$ was calculated as an increase in mass resulting from immersion expressed as a percentage of the mass of the dry specimen using equation (1) [18]:

$$
v=\frac{m_{W}-m_{D}}{m_{D}} \quad 100 \%
$$

where $m_{W}$ refers to a weight of the wet sample and $m_{D}$ is the weight of the dry sample. The concrete blocks were dried in an electric oven at $105 \pm 5^{\circ} \mathrm{C}$ to achieve constant mass. The water absorbability before and after the experiment was measured and calculated on the same specimens.

$X$-ray fluorescence analysis (XRF) was used to analyze the chemical composition of concrete samples and leachates. SPECTRO iQ II (Ametek, Germany) with silicon drift detector (resolution: $145 \mathrm{eV}$ at 10,000 pulses) was used for the elemental analysis of both liquid and solid phases [19]. The mass concentrations of leached ions in liquid phases are given in $\mathrm{mg} / \mathrm{L}$. The percentage of dissolved quantities were calculated from the initial content of the particular element in the concrete sample before the experiment and the total dissolved amount of the element.

\section{RESULTS AND DISCUSSION}

\subsection{Surface changes}

Figure 1 shows the surface changes on the concrete specimens prior (a) and after (b) the 6-week exposure to the aggressive acidic environment. Minimal visible changes were identified on concrete composites and based on the finding, a longer period of testing is needed to observe visible surface disruptions. 


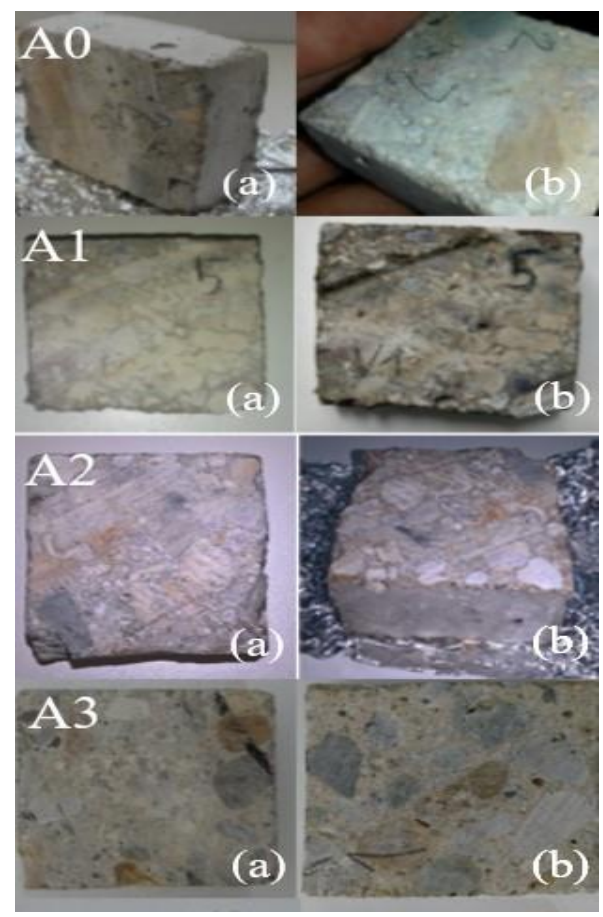

Figure 1 Surface changes of concrete composites after 6 week-long experiment

\subsection{Water absorbability}

Water absorbability values before (Voriginal) and after ( $\left.V_{\text {final }}\right)$ the sulfuric acid corrosion experiment are reported for all the studied concrete composites in Table 2.

Table 2 Water absorbability of concrete composites [\%]

\begin{tabular}{ccccc}
\hline Composite sample & $\boldsymbol{V}_{\text {original }}$ & $\boldsymbol{V}_{\text {final }}$ & $\boldsymbol{V}_{\text {final }}-\boldsymbol{V}_{\text {original }}$ & Change [\%] \\
\hline A0 & 6.32 & 6.66 & 0.34 & 5.4 \\
A1 & 5.53 & 6.09 & 0.56 & 10.1 \\
A2 & 5.05 & 5.40 & 0.35 & 6.9 \\
A3 & 4.73 & 5.19 & 0.46 & 9.7 \\
\hline
\end{tabular}

Obviously, the best value of water absorption coefficient was observed for the concrete with slag $(4.73 \%)$ followed by concrete with fly ash (5.05\%) and micro silica (5.53\%). The absorbability is linked with porosity of materials, which is a key factor to ensure the durability of concrete. The high porosity along with the ingress of moisture and other harmful chemicals such as sulfates affect the material and seriously reduce its strength and the life span of the structure. It is generally known that materials with low permeability last longer without showing signs of distress and deterioration and thus the permeation properties are used for determining the durability of concrete. A suitable solution is the use of an additive that seals the pores and cracks and thus reduces the permeability of the structure. The deterioration process due to acidic attack is manifested by the dissolution and releasing of the main cement matrix, and in connection with that by an increase in porosity and water absorbability.

The results showed that concrete without any secondary material possessed the worse water absorbability, exceeding $6 \%$, which was more than $30 \%$ higher compared to the slag-containing concrete. Similarly, the absorbability coefficients of concretes with added micro silica and fly ash improved by 14 and $25 \%$, respectively. This is in accordance with Pedro et al.'s findings [20]. Generally speaking, the average absorption of the good concretes ranged $4-6 \%$, whereas common commercial concrete products can reach the values up to $7 \%$ or even higher. It can be seen that water absorbability of all samples increased due to the acidic exposure, as expected. In spite of a higher percentage change of the water absorptivity, concrete samples with secondary materials still do not exceed the absorption value of $6 \%$ and exhibit better resistance against the transport of aggressive ions into 
unsaturated specimens. Recently, sorptivity has been recognized as a significant indicator of concrete durability [21]. The similar changes in absorbabilities of the samples with micro silica and slag due to sulfate attack confirm the suitable mix proportions of the analyzed concretes.

3.2 Chemical composition of leachates

Leaching trends of concrete samples with different waste by-products, regarding the main cement matrix elements, are illustrated in Figure 2a-d. As presented in Figure 2a, the highest amount of leached $\mathrm{Ca}^{2+}$ ions was observed for the A1 sample with micro silica $(441.1 \mathrm{mg} / \mathrm{L})$, while the lowest one was observed for the A2 sample with fly ash $(188.2 \mathrm{mg} / \mathrm{L})$.

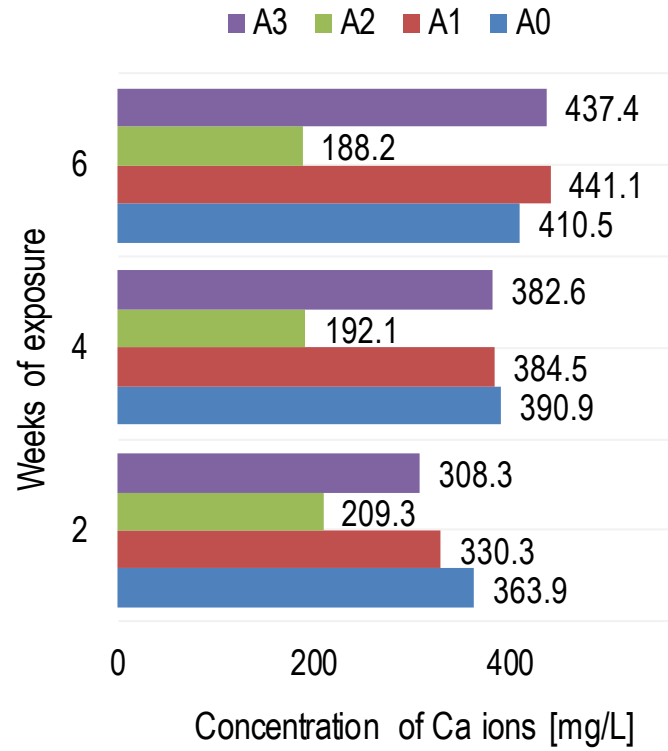

a)

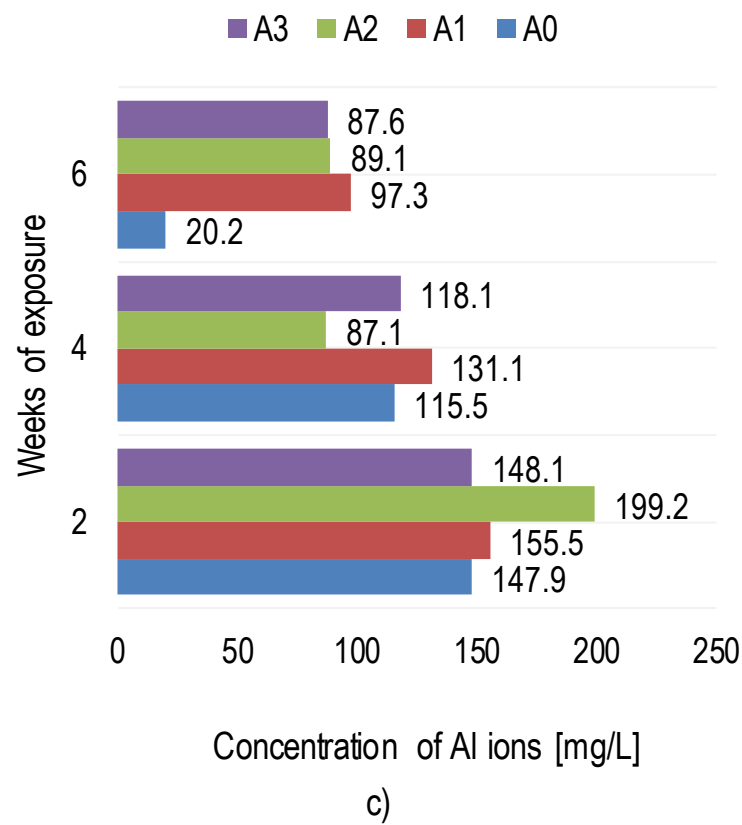

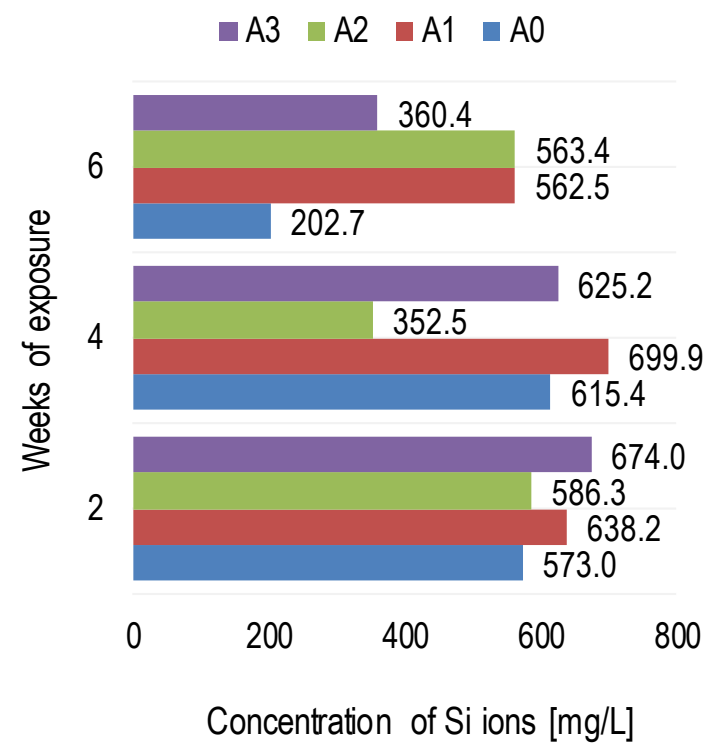

b)

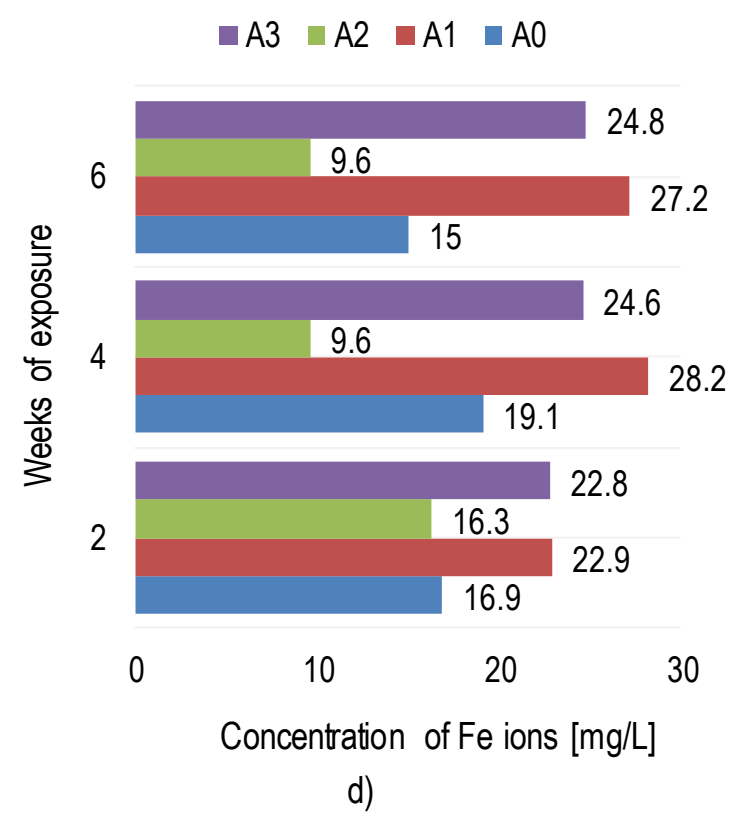

Figure 2 Leached masses of a) $\mathrm{Ca}^{2+}$, b) $\mathrm{Si}^{4+}$, c) $\mathrm{Al}^{3+}$, and d) $\mathrm{Fe}^{3+}$ ions during the 6-week experiment 
The course of concentration of $\mathrm{Si}^{4+}$ ions in leachates for all concrete samples was similar, with the highest concentrations measured after the $2^{\text {nd }}$ week of the experiment (Figure $2 \mathrm{~b}$ ). The highest concentration of $\mathrm{Al}^{3+}$ ions was observed in the leachate of the A2 $(199.2 \mathrm{mg} / \mathrm{L})$ sample after the $2^{\text {nd }}$ week of exposition to sulfuric acid (Figure 2c). The most intensive leaching of $\mathrm{Fe}^{3+}$ ions was observed for the sample with micro silica A1 (Figure 2d). The dissolved quantities of $\mathrm{Fe}^{3+}$ ions are low and, for the particular concrete sample, oscillate around the same value, during the entire experimental period. The decrease in concentrations of the ions in leachates during the experiment is likely caused by the recrystallization of the sulfate compounds on the concrete samples, as reported in [22].

To evaluate the durability of the concrete samples, the percentage of the dissolved elements was calculated as stated previously. The obtained values are given in Table 3 .

Table 3 Dissolved quantities of the main elements [\%]

\begin{tabular}{lcccc}
\hline & A0 & A1 & A2 & A3 \\
\hline Ca & 1.31 & 1.83 & 0.87 & 1.18 \\
Si & 2.08 & 0.92 & 3.53 & 1.29 \\
Al & 3.77 & 1.17 & 3.30 & 1.66 \\
Fe & 0.61 & 0.40 & 0.46 & 0.47 \\
\hline
\end{tabular}

The highest percentage of the dissolved elements was observed for the sample made with only ordinary CEM I Portland cement. The other concrete samples, with incorporated secondary materials, demonstrated better resistance in terms of lower leaching. This finding is valid for all analyzed elements except for calcium ions. Evaluating the dissolved quantities of $\mathrm{Ca}^{2+}$ ions, the $\mathrm{A} 1$ sample was found to be the least durable while the $\mathrm{A} 2$ sample, containing fly ash, was found to be the most durable in this corrosion simulation.

\section{CONCLUSION}

This paper presented the results of a durability study of concrete composites exposed to a chemical acidic attack during a period of 6 weeks. Surface changes, water absorptivity, and leachability of basic inorganic compounds were studied on concrete samples with different waste by-products (micro silica, fly ash, and blast furnace slag). The leaching test confirmed that sulfuric acid exposure has a degradation effect on all concrete composites. The samples with micro silica and slag were identified to be the most durable against the leaching of basic inorganic compounds of the cement matrix. The sample with fly ash was observed to have the lowest change in water absorbability. Results demonstrated that incorporating micro silica, fly ash, and slag in optimal proportions is an effective means of reducing the deterioration of concrete materials subjected to sulfate attack. However, different granulometic composition of incorporated waste materials could result in some differences in solid-phase reactions. Future research should be aimed at the pretreatment of waste materials to ensure the comparable size of the particles and consequently the analysis of the changes in composite properties.

\section{Acknowledgements}

This research has been supported by the Slovak Grant Agency for Sciences, projects No. 2/0145/15 and $1 / 0648 / 17$.

\section{References}

[1] Yuan H.; Dangla P.; Chatellier P.; Chaussadent T. 2013: Degradation modelling of concrete submitted to sulfuric acid attack, Cement and Concrete Research, 53, pp. 267-277, https://doi.org/10.1016/j.cemconres.2013.08.002

[2] Alani A. M.; Faramarzi A. 2014: An evolutionary approach to modelling concrete degradation due to sulphuric acid attack, Applied Soft Computing, 24, pp. 985-993, https://doi.org/10.1016/j.asoc.2014.08.044

[3] El Gamal M. M.; El-Dieb A. S.; Mohamed A. M. O.; El Sawy K. M. 2017: Performance of modified sulfur concrete exposed to actual sewerage environment with variable temperature, humidity and gases, Journal of Building Engineering, 11, pp. 1-8, https://doi.org/10.1016/j.jobe.2017.03.009 
[4] Debieb S. K. F.; Azzouz L. 2002: Mechanical properties and durability of concrete made with coarse and fine recycled aggregates, Sustainable Concrete Construction: Proceedings of the International Conference Held at the University of Dundee, Scotland, UK, 2, p. 383

[5] Omrane M.; Kenai S.; Kadri E. H.; Aït-Mokhtar A. 2017: Performance and durability of self-compacting concrete using recycled concrete aggregates and natural pozzolan, Journal of Cleaner Production, 165, pp. 415-430, https://doi.org/10.1016/j.jclepro.2017.07.139

[6] Hossain M. M.; Karim M. R.; Hossain M. K.; Islam M. N.; Zain M. F. M. 2015: Durability of mortar and concrete containing alkali-activated binder with pozzolans: A review, Construction and Building Materials, 93, pp. 95109, https://doi.org/10.1016/j.conbuildmat.2015.05.094

[7] Hewlett, P. 2003: Lea's chemistry of cement and concrete, Elsevier

[8] Stroeven P.; Stroeven M. 2001: Reconstructions by SPACE of the interfacial transition zone, Cement and Concrete Composites, 23 (2-3), pp. 189-200, https://doi.org/10.1016/S0958-9465(00)00076-7

[9] Paiva H.; Silva A. S.; Velosa A.; Cachim P.; Ferreira V. M. 2017: Microstructure and hardened state properties on pozzolan-containing concrete, Construction and Building Materials, 140, pp. 374-384, https://doi.org/10.1016/j.conbuildmat.2017.02.120

[10] Atahan H. N.; Dikme, D. 2011: Use of mineral admixtures for enhanced resistance against sulfate attack, Construction and Building Materials, 25 (8), pp. 3450-3457, https://doi.org/10.1016/..conbuildmat.2011.03.036

[11] Bondar D. 2009: Alkali activation of Iranian natural pozzolans for producing geopolymer cement and concrete, Doctoral dissertation: University of Sheffield

[12] Thomas M.; Hooton R. D.; Rogers C.; Fournier B. 2012: 50 years old and still going strong, Concrete international, $34(1)$

[13] Thomas M. D. 1996: Field studies of fly ash concrete structures containing reactive aggregates, Magazine of Concrete Research, 48 (177), pp. 265-279, https://doi.org/10.1680/macr.1996.48.177.265

[14] Hossain M. M.; Karim M. R.; Hasan M.; Hossain M. K.; Zain M. F. M. 2016: Durability of mortar and concrete made up of pozzolans as a partial replacement of cement: A review, Construction and Building Materials, 116, 128-140, https://doi.org/10.1016/j.conbuildmat.2016.04.147

[15] STN EN 206+A1, Concrete. Specification, performance, production and conformity, 2017

[16] Özbay E.; Erdemir M.; Durmuş H. İ. 2016: Utilization and efficiency of ground granulated blast furnace slag on concrete properties-A review, Construction and Building Materials, 105, 423-434, https://doi.org/10.1016/j.conbuildmat.2015.12.153

[17] Osborne G. J. 1999: Durability of Portland blast-furnace slag cement concrete, Cement and Concrete Composites, 21, 11-21, https://doi.org/10.1016/S0958-9465(98)00032-8

[18] STN 73 1316, Determination of moisture content, absorptivity and capillarity of concrete, 1989

[19] Kovalcikova M.; Estokova A.; Luptakova, A. 2015: Application of granulated blast furnace slag in cement composites exposed to biogenic acid attack, IOP Conference Series: Materials Science and Engineering, 96 (1), p. 012014, https://doi.org/10.1088/1757-899X/96/1/012014

[20] Pedro D.; De Brito J.; Evangelista L. 2018: Durability performance of high-performance concrete made with recycled aggregates, fly ash and densified silica fume, Cement and Concrete Composites, 93, 63-74, https://doi.org/10.1016/i.cemconcomp.2018.07.002

[21] Leung H. Y.; Kim J.; Nadeem A.; Jaganathan J.; Anwar M. P. 2016: Sorptivity of self-compacting concrete containing fly ash and silica fume, Construction and Building Materials, 113, 369-375, https://doi.org/10.1016/j.conbuildmat.2016.03.071

[22] Estokova A.; Smolakova M.; Luptakova A. 2018: Calcium Extraction from Blast-Furnace-Slag-Based Mortars in Sulphate Bacterial Medium, Buildings, 8(1), 9, https://doi.org/10.3390/buildings8010009

Please cite this article as:

Estokova, A.; Smolakova, M.: Investigation of concrete made with various wastes subjected to sulfuric acid attack, Electronic Journal of the Faculty of Civil Engineering Osijek-e-GFOS, 2018, 17, pp. 24-30, https://doi.org/10.13167/2018.17.3 